\title{
Subretinal cysticercosis with a mobile scolex
}

\author{
Deepa R Swamy, Ashish Markan, Shashwat Behera, Amar Pujari
}

Ophthalmology, Dr Rajendra Prasad Centre for Ophthalmic Sciences, AllMS, New Delhi, India

\section{Correspondence to Dr Amar Pujari, dramarpujari@gmail.com}

Accepted 22 January 2018

\section{DESCRIPTION}

A 26-year-old woman rushed to ocular emergency for recurrent sudden-onset pain, redness and congestion in the left eye. Visual acuity was 20/20 in the right eye and no perception of light in the left eye. History of trauma or any other ocular intervention was negative. Ocular examination revealed an unremarkable anterior and posterior segment in the right eye, whereas the left eye showed diffuse conjunctival congestion with a total leucomatous corneal opacity precluding the examination of the rest of the anterior and posterior segment. Immediate point-focused B-scan ultrasonography of the posterior segment revealed a total retinal detachment with a subretinal cyst harbouring a freely mobile, high-amplitude spike suggestive of live scolex (figure 1, online supplementary video 1). The slow movement of the freely floating cyst was also appreciated. On CT of the orbit and brain, any additional infection

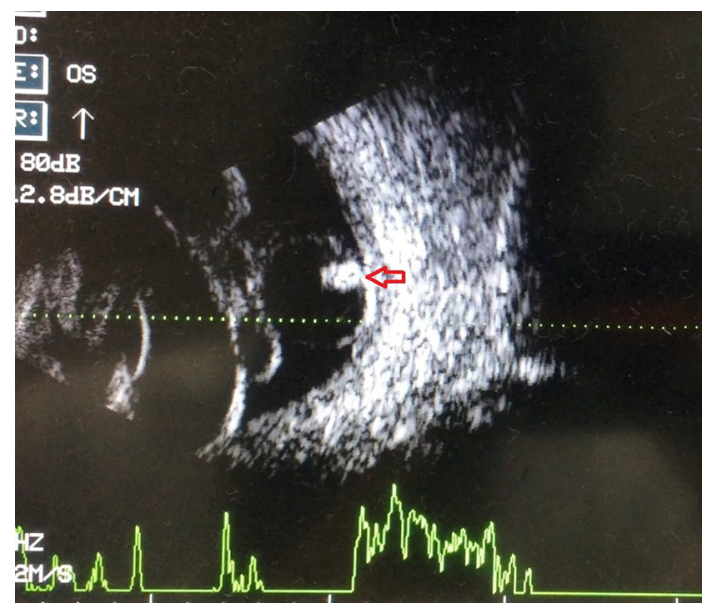

Figure 1 B-scan ultrasound of the posterior segment showing a total retinal detachment with a well-defined subretinal cyst having a high-amplitude, dot-like echo suggestive of mobile scolex.

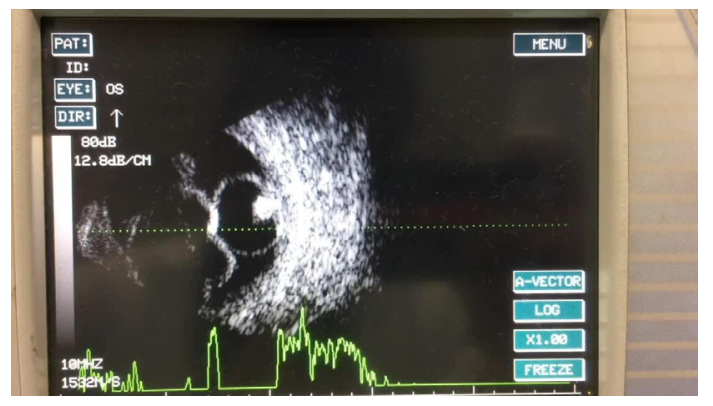

Video 1 Video of the B-scan ultrasound of the posterior segment showing a total retinal detachment with a welldefined subretinal cyst having a high-amplitude, dot-like echo suggestive of mobile scolex. foci were absent. A diagnosis of primary subretinal cysticercosis was confirmed after a positive ELISA testing. In view of hazy ocular media, no perception of light and risk of postoperative atrophic bulbi, surgical management was excluded and the patient opted for medical management. She was started on oral prednisolone acetate $1 \mathrm{mg} / \mathrm{kg}$ body weight from day 1 , followed by oral albendazole $15 \mathrm{mg} / \mathrm{kg}$ body per day in two divided doses from day 3 . The treatment was continued for 4 weeks, and at the end of treatment the scolex disappeared, with a partial collapse of the subretinal cyst, but the visual acuity remained with no perception of light.

In ophthalmic practice patients with a posterior segment disease need careful evaluation, which is quite accurately possible using indirect ophthalmoscope and other fundus photography techniques. However, the clinical scenario becomes more challenging in cases with anterior segment media opacity, where an accurate diagnosis is not possible in the majority of cases. In such cases, the clinician should rely on the available imaging modalities such as B-scan ultrasonography and/or MRI.

B-scan ultrasound is very quick and a reliable tool for bedside assessment of retinochoroidal pathologies. Especially in cases of ocular and orbital cysticercosis where a definite clinical appreciation of the cyst is not possible, an ultrasonic identification of a cyst harbouring a scolex is the most reliable sign and thus the assessment of treatment response during the treatment course. ${ }^{12}$

Learning points

- Patients with anterior segment media opacity may harbour significant posterior segment pathology.

- B-scan ultrasonography is a reliable tool for the diagnosis and monitoring of the posterior segment infection as well as non-infectious retinochoroidal disease entities.

Contributors DRS, AM, SB and AP have evaluated the case in detail, followed by optimal medical management. DRS, AM, SB and AP after critically analysing the educational value of the case wrote the report together.

Funding This research received no specific grant from any funding agency in the public, commercial or not-for-profit sectors.

Competing interests None declared.

Patient consent Obtained.

Provenance and peer review Not commissioned; externally peer reviewed.

(C) BMJ Publishing Group Ltd (unless otherwise stated in the text of the article) 2018. All rights reserved. No commercial use is permitted unless otherwise expressly granted. 


\section{REFERENCES}

1 Pujari A, Chawla R, Singh R, et al. Ultrasound-B scan: an indispensable tool for diagnosing ocular cysticercosis. BMJ Case Rep 2017 [Epub ahead of print 21 Apr 2017].
2 Pujari A, Behera AK. Medial rectus muscle cysticercosis: an assessment using ultrasonography and CT. BMJ Case Rep 2016. doi: 10.1136/bcr-2016-217953.[Epub ahead of print 14 Nov 2016].

Copyright 2018 BMJ Publishing Group. All rights reserved. For permission to reuse any of this content visit http://group.bmj.com/group/rights-licensing/permissions.

BMJ Case Report Fellows may re-use this article for personal use and teaching without any further permission.

Become a Fellow of BMJ Case Reports today and you can:

- Submit as many cases as you like

- Enjoy fast sympathetic peer review and rapid publication of accepted articles

- Access all the published articles

- Re-use any of the published material for personal use and teaching without further permission

For information on Institutional Fellowships contact consortiasales@bmjgroup.com

Visit casereports.bmj.com for more articles like this and to become a Fellow 